\title{
MANAJEMEN PENDIDIKAN KARAKTER MELALUI KEGIATAN KOKURIKULER KEAGAMAAN
}

\author{
DEA FARHANI \\ Universitas Islam Negeri Sunan Gunung Djati Bandung \\ Jl. A.H Nasution No.105 Cibiru Bandung \\ Email: farhanidea9@gmail.com
}

\begin{abstract}
ABSTRAK
Tujuan penelitian ini yaitu untuk mengetahui bagaimana manajemen pendidikan karakter melalui kegiatan kokurikuler mulai dari perencanaan, pengorganisasian, pelaksanaan, pengendalian, hasil dan faktor pendukung dan penghambat pendidikan karakter melalui kegiatan kokurikuler terhadap peserta didik. Penelitian ini berangkat dari pemikiran mengenai fungsi manajemen menurut G.R Terry yaitu planning, organizing, actuating, controling untuk mencapai tujuan lembaga yang telah ditentukan. Maka manajemen yang baik sangat dibutuhkan dalam kegiatan pendidikan karakter di MTs Ar-Raudloh yaitu perencanaan, pengorganisasian, pelaksanaan dan pengendalian pendidikan karakter untuk mewujudkan tujuan pendidikan karakter dalam kegiatan kokurikuler keagamaan. Penelitian ini menggunakan pendekatan kualitatif dengan metode deskriptif. Dari hasil penelitian ini data yang ditemukan dapat disimpulkan perencanaan pendidikan karakter adanya nilai-nilai yang ditanamkan yaitu mandiri, ikhlas, jujur, bertanggung jawab dan santun. Pengorganisasian pendidikan karakter dilakukan dengan struktur organisasi yang jelas dan tugas tupoksi yang jelas. Pelaksanaan pendidikan karakter dilakukannya shalat duha sebelum melaksanakan pembelajaran, shalat dzuhur berjamaah, bimbingan tilawah. Pengendalian pendidikan karakter dilakukan dengan cara monitoring setiap kegiatan kokurikuler keagamaan dan selalu mengadakan evaluasi setiap satu minggu sekali. Keberhasilan pendidikan karakter dapat dilihat dari kriteria keberhasilan, efektif dan eflsien manajemen pendidikan karakter. Faktor penunjang pendidikan karakter adalah SDM, sarana dan prasarana, standar mutu dan cara pandang masyarakat terhadap pendidikan.
\end{abstract}

Kata kunci: Manajemen, Pendidikan Karakter, Kokurikuler

\section{ABSTRACT}

The purpose of this study is to find out how the management of character education through co-curricular activities ranging from planning, organizing, implementing, controlling, results and supporting factors and inhibiting character education through co-curricular activities for students. This research departs 
from thinking about management functions according to G.R Terry, namely planning, organizing, actuating, controling to achieve the objectives of a predetermined institution. So good management is needed in character education activities at MTs Ar-Raudloh, namely planning, organizing, implementing and controlling character education to realize the character education goals in religious co-curricular activities. This study uses a qualitative approach with descriptive methods. From the results of this study, the data found can be concluded that character education planning implies values that are independent, sincere, honest, responsible and polite. Organizing character education is carried out with a clear organizational structure and clear tasks of duties. The implementation of character education in performing duha prayers before carrying out learning, midday prayer in congregation, tilawah guidance. Character education control is carried out by monitoring every religious curricular activity and always evaluating once a week. The success of character education can be seen from the success criteria, effective and efficient management of character education. Factors supporting character education are human resources, facilities and infrastructure, quality standards and the community's perspective on education.

Keywords: Management, Character Education, Kokurikuler

\section{PENDAHULUAN}

Secara estimologis, manajemen berasal dari bahasa latin, yakni dari asal kata "manus" yang berarti tangan dan "agere" yang berarti melakukan. Dalam bahasa Inggris dikenal dengan kata manage yang berarti mengurus, mengatur, melaksanakan dan mengelola (Jahari \& Syarbini, 2013, hlm. 3).

Manajemen adalah ilmu dan seni yang mengatur proses pemanfaatan sumber daya manusia secara efektif dengan didukung oleh sumber-sumber lainnya dalam suatu organisasi untuk mencapai tujuan. Dalam pengertian ini terdapat dua sistem yang harus selalu ada dalam manajemen, yaitu sistem organisasi dan sistem administrasi (Athoillah, 2010, hlm. 14).

Pendidikan merupakan usaha sadar dan terencana dalam proses pengubahan sikap dan tata laku seseorang atau kelompok dalam mengembangkan potensi dirinya atau usaha mendewasakan manusia melalui upaya pembelajaran dan pelatihan. Kualitas pendidikan tidak semata-mata diukur dari mutu keluaran pendidikan secara utuh akan tetapi dikaitkan dengan konteks dimana mutu itu harus ada dalam standar pendidikan nasional (Akhwan, 2008).

Tujuan pendidikan adalah untuk membentuk pribadi yang berkualitas dan berkarakter, yang mampu beradaptasi secara cepat dan tepat terhadap lingkungan sekitar sehingga memiliki cara pandang yang luas kedepan untuk mencapai suatu cita-cita yang diharapkan.

Karakter adalah nilai-nilai yang khas baik (tahu nilai kebaikan, mau berbuat baik, nyata berkehidupan baik) yang terpatri dalam diri dan terwujud dalam prilaku. Hubungannya dengan pendidikan, pendidikan karakter dapat dimaknai sebagai pendidikan nilai, pendidikan budi pekerti, pendidikan moral, pendidikan watak, yang bertujuan mengembangkan kemampuan siswa untuk memberikan keputusan baik buruk, memelihara kebaikan, mewujudkan dan 
menebar kebaikan dalam kehidupan sehari-hari dengan sepunuh hati (Setiawati, 2017, hlm. 348).

Pendidikan karakter merupakan pondasi utama bagi suatu bangsa dalam membentuk perkembangan jiwa anak baik lahir maupun batin. Oleh karena itu, dalam tujuan pendidikan karakter, perlu ada manajemen yang baik dan sinergis di antara berbagai komponen pendidikan yang terlibat baik yang bersifat formal, nonformal, maupun informal, baik di sekolah, keluarga, maupun masyarakat.

Pendidikan karakter disekolah, semua komponen (stakeholders) harus dilibatkan, termasuk komponen-komponen pendidikan itu sendiri, yaitu isi kurikulum proses pembelajaran dan penilaian, kualitas hubungan, penanganan atau pengelolaan mata pelajaran, pengelolaan sekolah, pelaksanaan aktivitas, pemberdayaan sarana dan prasarana, pembiayaan, dan etos kerja seluruh warga dan lingkungan sekolah (Citra, 2012, hlm. 239). Pendidikan karakter merupakan upaya untuk membantu perkembangan jiwa anak-anak baik lahir maupun batin, dari sifat kodratinya menuju ke arah peradaban yang manusiawi dan lebih baik (Mulyasa, 2016, hlm. 1).

Pendidikan karakter selalu diupayakan untuk masuk ke dalam kurikulum pendidikan di berbagai jenjang dan jenis, sehingga diatur dalam Pasal 3 Undang-Undang Sistem Pendidikan Nasional, yaitu Pendidikan nasional berfungsi mengembangkan kemampuan dan membentuk watak serta peradaban bangsa yang bermartabat dalam rangka mencerdaskan kehidupan bangsa, bertujuan untuk mengembangkan potensi peserta didik agar menjadi manusia yang beriman dan bertakwa kepada Tuhan Yang Maha Esa, berakhlak mulia, sehat, berilmu, cakap, kreatif, mandiri, dan menjadi warga negara yang demokratis serta bertanggung jawab.

Membentuk siswa yang memiliki karakter yang baik bukan hal yang mudah dan cepat. Hal tersebut memerlukan usaha dan upaya secara terus menerus dan refleksi mendalam untuk membuat urutan kebijakan yang harus ditindak lanjuti dengan aksi nyata, sehingga menjadi hal yang praktis dan reflektif (Isnaini, 2018, hlm. 37).

Karakter merupakan perilaku, watak, sifat kejiwaan, akhlak atau budi pekerti yang membedakan seseorang dengan orang lain (Syarbini, 2012, hlm. 13). Karakter tidak dapat dibentuk karena karakter merupakan bawaan sejak lahir (Lestari, 2016, hlm. 77). Namun ada lagi pendapat lain yang mengatakan bahwa karakter bukan bawaan sejak lahir karena karakter dapat dibentuk sejak usia peserta didik masih kecil (Yanti, Adawiah, \& Matnuh, 2016).

Karakter yang baik terbentuk dari hati dan tertuang menjadi perilaku, baik perilaku terpuji maupun perilaku tercela. Perilaku yang terpuji disebut akhlak yang mulia sedangkan perilaku yang tercela tidak termasuk ke dalam akhlak terpuji. Namun ada juga pendapat yang mengatakan bahwa akhlak tercela sering dikenal dengan akhlakul mazmumah (Zuhdi \& Rohaniawati, 2012, hlm. 53).

Manajemen pendidikan karakter di lembaga pendidikan islam dimulai dari perencanaan yang dilakukan oleh kepala sekolah, pengorganisasian program-program yang akan diimpilikasikan, selanjutnya diimplikasikan dalam setiap bidang studi oleh pendidik secara bersama-sama dengan penuh tanggung jawab di lembaga tersebut (Rusmaini, 2017, hlm. 147). 
Tujuan pendidikan karakter dalam perspektif islam adalah terbentuknya peserta didik yang memiliki karakter religius, jujur, berani, peduli sesama dan bertanggung jawab. Pada dasarnya tujuan ini merupakan kristalisasi nilai-nilai yang berfungsi sebagai pendorong dan memberikan makna yang jelas serta pengabsahan dari sebuah tindakan. Tujuan pendidikan karakter adalah melahirkan generasi-generasi muda yang beriman, jujur dan peduli pada sesamanya. Program pendidikan karakter merupakan bentuk penanaman nilai nilai karakter yang terdiri dari keteladanan yang dilakukan oleh pendidik di sekolah dan orang tua di rumah, pembiasaan diri peserta didik untuk melakukan hal-hal yang baik dan yang terkahir yaitu pemotivasian yang dilakukan oleh orang-orang yang ada di sekitar peserta didik (Hasanah, 2013, hlm. 336).

Kegiatan kokurikuler dilaksanakan di luar jadwal kegiatan intrakulikuler karena dituangkan dalam bentuk penugasan atau kegiatan yang dilakukan secara rutin di dan wajib diikuti oleh peserta didik. Dalam memberikan tugas kepada siswa, materi yang diberikan biasanya disesuaikan dengan bidang studi yang bersangkutan, karena penugasan tersebut dimaksudkan untuk memperdalam pengetahuan tentang materi yang di berikan di kelas.

Madrasah Tsanawiyah Ar-Raudloh Bandung dinaungi oleh Yayasan AlHasan, MTs Ar Raudloh sangat peduli terhadap pengembangan karakter dalam bidang keagamaan dengan mengoptimalkan pengembangan karakter khsususnya di bidang kegiatan kokurikuler keagamaan. Dengan sistem pendidikan yang islami untuk membentuk karakter peserta didik yang berahlakul karimah menjadi salah satu fokus utama yang selalu diterapkan dalam sistem pendidikan di MTs Ar Raudoh Bandung untuk mengembangkan pendidikan karakter yang dibutuhkan oleh generasi muda saat ini.

MTs Ar-Raudloh menyelenggarakan pendidikan karakter melalui kokurikuler keagamaan yang wajib dilaksanakan oleh seluruh peserta didik yaitu shalat duha. Shalat dzuhur dan shalat ashar berjamaah. Setelah shalat dzuhur diadakan kegiatan bimbingan tahsin dan tahfidz serta setiap bulan kegiatan muhadoroh di acara muhadoroh tersebut kegiatan ekstrakulikuler ditampilkan seperti nasyid dan marawis. Di MTs Ar-raudloh juga di wajibkan puasa sunnah senin dan kamis dan setiap hari senin dan kamis kantin sekolah tutup dan pedagang tidak diperbolehkan masuk ke arah sekolah.

Selanjutnya dalam penelitian ini penulis bermaksud mengungkap proses Manajemen pendidikan karakter melalui kegiatan kokurikuler keagamaan untuk dijadikan rekomendasi bagi sekolah lain terkait manajemen pendidikan karakter melalui kegiatan kokurikuler keagamaan.

\section{METODE PENELITIAN}

Penelitian ini menggunakan pendekatan kualitatif dengan metode deskriptif, yakni merupakan suatu metode dalam melakukan penelitian yang bertujuan untuk mendeskripsikan fenomena atau gejala yang bersifat alami pada tempat yang diteliti. Teknik pengumpulan data dilakukan dengan cara wawancara, observasi, dan dokumentasi. data tersebut berupa kata-kata, catatan, laporan dan dokumen yang diperoleh dari kepala sekolah, wakil kepala bidang kesiswaan, wakil kepala bidang kurikulum dan guru MTs Ar-Raudloh. 
Data-data tersebut dikumpulkan untuk kemudian disimpulkan sebagai hasil penelitian setelah dilakukan analisis dan uji keabsahan terhadap tersebut.

\section{HASIL DAN PEMBAHASAN \\ Perencanaan Pendidikan Karakter Melalui Kegiatan Kokurikuler Keagamaan}

Perencanaan pendidikan karakter di madrasah Perencanaan dalam pendidikan karakter harus menanamkan kesadarab bersama dan menyamakan presepsi akan pentingnya pengintegritasan nilai yang ada pada semua aktivis yang ada di madrasah, sehingga nilai tersebut bisa menjadi habit (kebiasaan) oleh semua stakeholder madrasah. Langkah kongkrit yang bisa dilakukan adalah mensosialisasikan akan pentingnya pendidikan karakter di madrasah dengan didasarkan pada output pendidikan selama ini yang kurang menghargai pendidikan nilai/karakter serta proyeksi kebutuhan sumber daya manusia yang penuh dengan kompetisi global. Perlu ditegaskan juga dengan dasar atau regulasi tentang perlunya sekolah atau madrasah menerapkan pendidikan karakter, regulasi atau dasar pengambilan hukum tentang perlunya pelaksanaan pendidikan karakter di madrasah harus dapat dipahami oleh semua stakeholder madrasah dan mampu melaksanakan secara sadar dan bertanggung jawab terhadap pelaksanaan pembelajaran yang akan dilaksanakannya (Salim, 2015, hlm. 10).

Visi Madrasah Tsanawiyah Ar-Raudloh adalah "Terbentuknya Peserta Didik yang unggul, pribadi yang mandiri, dan berakhlakul karimah", penjelasan mengenai visi MTs Ar-Raudloh yaitu membentuk peserta didik yang unggul, mandiri dan berakhlakul karimah yang mampu mengoptimalkan kecerdasan dengan pribadi yang mandiri dan berakhlakul karimah sesuai dengan Al-Quran dan as-Sunnah dengan berorientasi pada Allah Semata, senantiasa benar dalam niat,ucupan dan jujur. Melaksanakan kewajiban untuk memberikan manfaat kepada yang lain dengan penuh tanggung jawab, serta memiliki pribadi yang bisa berkomunikasi dan bersosialisasi dengan santun.

Sedangkan Misi Madrasah Tsanawiyah Ar-Raudloh berfikir secara logis, kritis, kreatif, Inovatif dalam memecahkan masalah, mampu bersaing dalam mengikuti berbagai kompetensi akademik dan non akademik, mampu melanjutkan pendidikan ke jenjang selanjutnya yang terbaik sesuai pilihannya melalui pencapaian target pilihan yang ditentukan sendiri berpartisipasi dalam kehidupan sebagai cerminan rasa cinta dan bangga terhadap tanah air dan bangsa, mampu menampilkan kebiasaan sopan santun dan budi pekerti sebagai cerminan akhlak mulia.

Nilai Karakter yang dikembangkan oleh Madrasah Tsanawiyah ArRaudloh adalah 5 karakter yaitu: Karakter Mandiri, kerakter Jujur, Karakter Ikhlas, Karakter Tangung Jawab dan Karakter Santun.

Penanaman nilai nilai karakter melalui kegiatan kokurikuler keagamaan adalah dengan pembiasasaan melaksanakn shalat duha setiap hari sebelum belajar, shalat dzuhur dan ashar berjamaah meskipun ada pemaksaan dari pihak sekolah tatapi itu jadi prilaku yang baik untuk kehidupan mereka jadi mereka terbiasa dengan kegiatan tersebut sehingga ketika peserta didik berada di luar sekolah pun mereka melaksanakan hal tersebut. Penanaman nilai-nilai karakter pada kurikulum dan pembelajaran. Dalam kurikulum adanya pelaksaan 
shalat duha dan untuk memulai belajar setiap pendidik itu berbeda beda untuk penguatan karakter ada yang harus baca al-quaran terlebih dahulu ada yang harus membaca asamul husna dan ada kata kata tentang karakter akhlakul karimah. Penanaman nilai-nilai karakter pada pendidik dan tenaga kependidikan dilaksanakan setiap pagi sebelum masuk kelas adanya briefing untuk memotivasi kepada guru dalam melaksanakan tugas kepada sebagai pengajar. Penanaman nila-nilai karakter melalui sarana prasana dengan adanya shalat duha di masjid sebelum masuk kelas, upacara, olahraga dan apapun kegiatan yang dilaksanakan adalah selalu mengarah pada kegiatan penguatan karkater.

\section{Pengorganisasian Pendidikan Karakter Melalui Kegiatan Kokurikuler Keagamaan}

Dalam pengorganisasian adanya pembagian pekerjaan kepada orang berdasarkan kepada kemampuannya. Beberapa hal yang perlu mendapat perhatian dalam pengorganisasian adalah bahwa pembagian tugas dan wewenang serta tanggung jawab seharusnya disesuaikan dengan kompetensi, minat, bakat dan pengalaman serta kepribadian masing-masing orang yang diperlukan dalam menjalankan beberapa tugas tersebut. Konsep "the right man on the right place" harus selalu menjadi acuan stakeholder madrasah dalam melaksanakan ini. Seorang yang mempunyai wewenang secara struktur organisasi untuk mendelegasikan tugas atau wewenang yang dimilikinya kepada stakeholder madrasah. Kegiatan pengorganisasian terkait dengan pendidikan karakter yang paling banyak berperan adalah guru sebagai agent of instruction di madrasah. Guru madrasah harus siap diberi tugas dan tanggung jawab yang berhubungan dengan penguatan karakter di madrasah baik terkait penyampaian materi atau kegiatan yang dilaksanakan di madrasah (Salim, 2015, hlm. 10)

Pengorganisasian merupakan fungsi manajemen yang mencakup kegiatan-kegiatan sebagai berikut: (1) danya pembagian kerja (job description) yang jelas, (2) pembagian aktivitas menurut level kekuasaan dan tanggung jawab, (3) pembagian dan pengelompokan tugas menurut mekanisme koordinasi kegiatan individu dan kelompok, (4) pengaturan hubungan kerja antar anggota organisasi (Wibowo, 2013, hlm. 148-149).

Kegiatan pengorganisasiannya yaitu: adanya pembagian kerja di awal tahun pada saat rapat kerja adanya kontrak kerja, pembagian kerja (job description) untuk kepala madrasah, wakil kepala madrasah, guru, tenaga administrasi yang rinci dan jelas apa saja yang akan dilakukan untuk satu tahun kedepan. Pembagian aktifitas menurut level kekuasaan dan tanggung jawab dilakukan sesuai sesuai alur kasus anak yang bertanggung jawa adalah guru, kemudian ke wali kelas lalu ke kepala madrasah baru ke kepala yayasan. Untuk kasus yang ke kepala madrasah biasa kasus yang berat dan di buku birunya sudah mencapai 100 poin melakukan sanksi pelanggaran maka akan di drop out dari sekolah. Pengaturan hubungan kerja antar anggota organisasi dilakukan musyawarah, musyaawarah antar guru kelas dan kepala sekolah, dan musyawarah guru, staf, kepala sekolah dan yayasan.

Langkah langkah pengorganisasiannya yaitu: merinci tugas-tugas yang harus di laksanakan oleh guru dan satf untuk mencapai tujuan pendidikan karakter dilakukan diawal pembelajaran dan diadakannya kegiatan-kegiatan 
untuk mencapai indikator-indikator karakter mandiri, jujur, ikhlas, tanggung jawab, santun. Membagi seluruh tugas/beban kerja yang dilaksanakan oleh guru dan staf. Pembagian tugas guru dilakukan oleh kepala madrasah maksimal beban kerja 30 Jam tatap muka dan minimal 24 jam tatap muka. Menyatukan atau mengelompokan tugas para guru dan staf, dengan cara yang rasional dan efisien, dilakukan dengan adanya kelompok kerja guru untuk guru Keagamaan dan Guru Sains. Menetapkan mekanisme kerja untuk mengkordinasi pekerjaan dalam satu kesatuan yang harmonis dengan adanya tugas dan fungsi setiap guru dan jadwal kegiatan. Melakukan monitoring dan mengambil langkah-langkah penyesuaian untuk meningkatkan pelaksanaan pendidikan karakter. Laporan tentang kokurikuler keagamaan tersebut itu biasanya dilakukan pertriwulan terkait praktik ibdah, untuk hasil dari muhadoroh dilombakan di acara Peringatan Hari Besar Islam (PHBI) dan untuk Buku Biru di cek setiap minggu.

\section{Pelaksanaan Pendidikan Karakter Melalui Kegiatan Kokurikuler Keagamaan}

Pelaksaan merupakan usaha menggerakan anggota-anggota kelompok sedemikian rupa, hingga mereka berkeinginan dan berusaha untuk mencapai tujuan yang telah direncanakan bersama (Terry, 2010, hlm. 62).

Fungsi pelaksanaan pendidikan karakter yaitu: Mengadakan orientasi sebelum tenaga pengajar memulai melaksanakan tugas dalam hal melaksanakan pendidikan karakter dilakukan dengan rapat kerja dan pelatihanpelatihan. Kalau rapat kerja musyawarah satu tahun. Sedangkan pelatihan yang berkaitan dengan guru yang berkaitan dengan pendidikan karakter tiap seminggu sekali ada mentoring. Memberikan petunjuk dan penjelasan mengenai implementasi pendidikan karakter yang dilakukan secara lisan maupun tertulis. Secara lisan ada penjelasan dari Wakamad Kesiswaan dan untuk yang tertulis nya ada buku karakter yaitu dinamakan buku biru. Memberikan kesempatan kepda guru dan staf untuk berpartisipasi berupa pemberian sumbangan pikiran demi tercapainya tujuan pendidikan karakter di madrasah. Untuk usulan dari guru ke kepala madrasah, dari kepala madrasah ke yayasan usulan tersebut ada yang ditolak ada yang diterima, ada juga rapat tapi jadwalnya tidak tentu bersama dengan pihak yayasan. Guru terlibat langsung dalam pelaksanaan pendidikan karakter karena guru pun harus mengikuti kegiatan khususnya kegiatan kokurikuler keagamaan seperti puasa senin dan kamis, shalat dhuha, shalat dzuhur dan ashar berjamaah.

Peran Kepala Madrasah yaitu: Peran kepala madrasah sangat berperan untuk mengontrol guru guru tetapi untuk manajemennya yang lebih berperan adalah pihak yayasan. Peran manajerial. Berkaitan dengan controling dan supervisi yang kuat satu semester sekali yang berkaitan dengan pelaksanaan pembelajaran dan administrasi, dll.

\section{Pengendalian Pendidikan Karakter Melalui Kegiatan Kokurikuler Keagamaan}

Pengendalian dalam pendidikan karakter berfungsi untuk melihat apakah program-program pendidikan karakter yang telah disepakati dan didistribusikan kepada guru dan staf telah dilaksanakan sesuai dengan standar operasioanal 
pelaksanaan atau belum. Pengendalian yang dilakukan kepala sekolah bukan bertujuan untuk mencari-cari kesalahan guru dan staf, tetapi untuk memperbaiki proses dalam rangka perbaikan hasil (Wibowo, 2013, hlm. 172).

Proses Pengendalian Penetapan standar. Dilakukan dengan cara adanya standar tertulis yang dimiliki setiap kelasnya. Membandingkan pelaksaan program dengan standar tersebut. Dialakukan dengan evaluasi setiap satu bulan. Kebanyakan masih belum mencapai target dan belum konsisten yang berkaitan dengan karakter contohnya seperti membersihkan ruangan kelas. Perbaikan terhadap kesalahan-kesalahan yang terjadi dilakukan evaluasi dengan cara dikurangi jika terlalu berat dan ditambahkan jika terlalu ringan satu semseter sekali diadakan evaluasi.

Tujuan monitoring dan evaluasi yaitu: melakukan pengamatan dan pembimbingan secara langsung keterlaksanaan program pendidikan karakter di madrasah dengan adanya supervisi kepada guru-guru satu kelas satu kali dalam satu semester. Memperoleh gambaran mutu pendidikan karakter di madrasah dengan data yang dikumpulkan. Melihat kendala-kendala yang terjadi dalam pelaksanaan program dan mengidentifikasi masalah yang ada dan selanjutnya mencari solusi agar program pendidikan karakter yang sesuai dengan visi dan misi tercapai. Mengumpulkan data yang ditemukan dilapangan untuk menyusun rekomendasi terkait perbaikan pelaksanaan program pendidikan karakter ke depan.

\section{Hasil Manajemen Pendidikan Karakter Melalui Kegiatan Kokurikuler Keagamaan}

Kriteria keberhasilan manajemen pendidikan karakter meliputi: (1) karakter yang ditanamkan sesuai dengan perkembangan peserta didik, dan mereka memandang bahwa hal tersebut akan sangat berguna bagi kehidupan kelak, (2) para peserta didik menjadi insan yang berkarakter, kreatif dan mampu menghadapi berbagai permasalahan yang dihadapinya serta tidak memberikan dampak negatif dalam kehidupan bermasyarakat, (3) adanya peningkatan mutu pendidikan yang dapat dicapai oleh sekolah melalui kemandirian, inisiatif kepala sekolah dan guru dalam melaksanakan pendidikan karakter disekolah, (4) adanya peningkatan efesiensi dan efektivitas pengelolaan dan penggunaan sumber-sumber belajar pendidikan karakter, melalui pembagian tanggung jawab yang jelas, transparan dan demokratis, (5) adanya peningkatan perhatian serta partisipasi warga masyarakat sekolah dalam penyelenggaraan pendidikan karakter yang dicapai melalui pengambilan keputusan bersama, (6) terciptanya iklim sekolah yang aman, nyaman, dan tertib sehingga proses pembelajaran dapat berlangsung dengan tenang menyenangkan (Mulyasa, 2016, hlm. 216217).

Indikator keberhasilan manajemen pendidikan karakter melalui kegiatan kokurikuler keagamaan yang ditanamkan sesuai dengan perkembangan peserta didik, dan mereka memandang bahwa hal tersebut akan sangat berguna bagi kehidupannya kelak. Mengenai lulusan juga banyak yang dilanjutkan ke MA Ar-Raudloh karena peserta didik merasa nyaman dengan adanya kegiatan kegiatan yang dilaksanakan di madrasah contohnya dengan adanya kegiatan kokurikuler. Para peserta didik menjadi insan yang berahlakul karimah dan mampu menghadapi berbagai permasalahan yang dihadapinya 
serta tidak memberikan dampak negatif dalam kehidupan bermasyarakat. Adanya peningkatan mutu pendidikan yang dapat dicapai oleh sekolah melalui kemandirian, kepala madrasah dan guru dalam melaksanakan pendidikan karakter di madrasah. Ada peningkatan perhatian dari orang tua mengenai anaknya tentang shalat dan bacaan al-qurannya. Respon masyarakat positif dengan adanya kegiatan kokurikuler keagamaan ini. Terciptanya iklim sekolah aman, nyaman dan tertib sehingga proses pembelajaran dapat berlangsung dengan tenang. Dari segi keamanan, kenyamanan dan tertib sudah optimal.

Efektifitas proses dan produk dilakukan dengan cara dibuatnya jadwal, targetan yang ingin dicapai jelas, dan dengan adanya kegiatan kokurikuler keagamaan bisa menguatkan pendidikan karakter terhadap peserta didik. Produk program pendidikan karakter di buat oleh kurikulum. Efesien proses dan produk. Supaya efesien dalam pendidikan karakter yang tergetannya besar. Maka untuk penguatan pendidikan karakter tidak hanya dilaksanakan pada kegiatan kokurikuler keagamaan saja tetapi pada kegiata-kegiatan lain pun seperti pembelajaran adanya pendidikan karakter karena warga madrasah semua terlibat dalam pendidikan karakter yang ingin dicapai. Produk karakter yang dibuat membuat peserta didik menikmati dengan kegiatan tersebut dan tidak membebankan.

Tabel 1. Indikator Keberhasilan Pendidikan Karakter MTs Ar-Raudloh

\begin{tabular}{|c|c|c|c|}
\hline No & $\begin{array}{l}\text { Karakter Yang } \\
\text { Dikembangkan }\end{array}$ & Indikator Keberhasilan & $\begin{array}{c}\text { Keterca } \\
\text { paian }\end{array}$ \\
\hline 1 & $\begin{array}{l}\text { Karakter } \\
\text { Mandiri }\end{array}$ & $\begin{array}{l}\text { 1. Merima diri sebagai laki-laki atau } \\
\text { perempuan } \\
\text { 2. Menerima keadaan diri sebagai bagian } \\
\text { dari lingkungan } \\
\text { 3. Memahami prilaku hemat ulet, sungguh } \\
\text { sungguh kompetitif dalam kehidupan } \\
\text { disekitarnya. } \\
\text { 4. Berpikir secara logis,kritis, kreatif dan } \\
\text { inovatif. }\end{array}$ & $\begin{array}{l}\text { Mulai } \\
\text { Terbiasa }\end{array}$ \\
\hline 2 & Karakter Jujur & $\begin{array}{l}\text { 1. Mengetahui Biografi Nabi Muhammad } \\
\text { SAW } \\
\text { 2. Berprilaku sopan dan santun } \\
\text { 3. Menghormati yang lebih tua serta } \\
\text { menghargai teman } \\
\text { 4. Mengucapka salam } \\
\text { 5. Saling tolong menolong }\end{array}$ & $\begin{array}{l}\text { Mulai } \\
\text { Terbiasa }\end{array}$ \\
\hline 3 & Karakter Ikhlas & $\begin{array}{l}\text { 1. Mengagungkan dan mengagumi Allah } \\
\text { pencipta seluruh alam } \\
\text { 2. Berbuat baik terhadap sesama manusia } \\
\text { 3. Menjaga dan melesetarikan hewan dan } \\
\text { tumbuhan } \\
\text { 4. Berdoa untuk kedua orang tua } \\
\text { 5. Tidak menyakiti orang lain } \\
\text { 6. Memiliki respon yang cepat ketika } \\
\text { medengar adzan }\end{array}$ & $\begin{array}{l}\text { Mulai } \\
\text { Terbiasa }\end{array}$ \\
\hline
\end{tabular}




\begin{tabular}{|c|c|c|c|}
\hline & & $\begin{array}{l}\text { 7. Bersegara melaksanakan wudhu } \\
\text { 8. Terbiasa melaksanakan shalat Wajib } \\
\text { yang } 5 \text { Waktu } \\
\text { 9. Terbiasa Shalat Sunnah Rawatib dan } \\
\text { Dhuha } \\
\text { 10. Terbiasa berdzikir setelah selesai shalat } \\
\text { 11. Terbiasa berinfaq }\end{array}$ & \\
\hline 4 & $\begin{array}{l}\text { Karakter } \\
\text { Tanggung } \\
\text { Jawab }\end{array}$ & $\begin{array}{l}\text { 1. Terbiasa bangun subuh tepat waktu } \\
\text { 2. Terbiasa tidur setelah shalat Isya } \\
\text { 3. Dapat mengatur diri sendiri } \\
\text { 4. Mengakui kesalahan } \\
\text { 5. Mengikuti teladan orang yang baik } \\
\text { 6. Senang berbagi }\end{array}$ & $\begin{array}{l}\text { Mulai } \\
\text { terbiasa }\end{array}$ \\
\hline 5 & $\begin{array}{l}\text { Karakter } \\
\text { Santun }\end{array}$ & $\begin{array}{l}\text { 1. Selalu tersenyum dan mengucapkan } \\
\text { salam kepada orang lain } \\
\text { 2. Berbicara sopan dan santun } \\
\text { 3. Memanggil nama teman yang baik da } \\
\text { disukai } \\
\text { 4. Membantu orang lain } \\
\text { 5. Menuntun membimbing serta memberi } \\
\text { contoh yang baik kepada adik kelas } \\
\text { 6. Saling tolong menolong } \\
\text { 7. Saling menghargai } \\
\text { 8. Selalu mendahulukan teman yang lebih } \\
\text { membutuhkan } \\
\text { 9. Berkerja sama dengan siapapun }\end{array}$ & $\begin{array}{l}\text { Mulai } \\
\text { Terbiasa }\end{array}$ \\
\hline
\end{tabular}

\section{Faktor Pendukung dan Faktor Penghambat Manajemen Pendidikan Karakter Melalui Kegiatan Kokurikuler Keagamaan}

Menurut Akdon lingkungan internal meliputi kekuatan dan kelemahan organisasi. Kekuatan (strength) adalah situasi dan kemampuan internal yang bersifat positif yang memungkinkan organisasi memenuhi keuntungan starategik dalam mencapai visid dan misi. Sedangkan kelemahan (Weekness) adalah situasi dan faktor-faktor luar organisasi yang bersifat negatif dan menghambat organisasi mencapai atau melampaui pencapaian visi dan misi (Badrudin, 2013, hlm. 102).

Lingkungan eksternal meliputi peluang dan tantangan organisasi. Peluang (Opportunity) adalah situasi dan faktor-faktor organisasi yang bersifat positif dan membantu organisasi mencapai atau mampu melampaui pencapaian visi dan misi. Sedangkan tantangan (thearts) adalah faktor-faktor luar organisasi yang bersifat negatif dan dapat mengakibatkan organisasi gagal dalam mencapai visi dan misi (Badrudin, 2013, hlm. 103).

Faktor pendukung pendidikan karakter (kekuatan): Potensi fisik dan fasilitas sarana dan prasarana, potensi tenaga pendidik, kegiatan kokurikuler keagaamaan. Faktor pendukung pendidikan karakter (Peluang): peningkatan mutu akademik dan pengembangan pendidikan karakter. 
Faktor penghambat pendidikan karakter (kelemahan); Sisi manajemen Pengelolaan, sisi pengalaman pendidik, akses Jalan. Faktor Penghambat pendidikan karakter (tantangan): Standar mutu pengelolaan sekolah, cara pandang masyarakat terhadap pendidikan secara umum.

\section{SIMPULAN}

Perencanaan program pendidikan karakter adanya penanaman nilai-nilai sesuai dengan visi dan misi dengan diekmbangkannya 5 Nilai Karakter oleh Madrasah Tsanawiyah Ar-Raudloh yaitu : Karakter Mandiri, kerakter Jujur, Karakter Ikhlas, Karakter Tangung Jawab dan Karakter Santun.

Pengorganisasian adanya pembagian pekerjaan kepada orang berdasarkan kepada kemampuannya. Beberapa hal yang perlu mendapat perhatian dalam pengorganisasian adalah bahwa pembagian tugas dan wewenang serta tanggung jawab seharusnya disesuaikan dengan kompetensi, minat, bakat dan pengalaman serta kepribadian masing-masing orang yang diperlukan dalam menjalankan beberapa tugas tersebut.

Pelaksanaan pendidikan karakter yaitu: Memberikan petunjuk dan penjelasan mengenai implementasi pendidikan karakter yang dilakukan secara lisan maupun tertulis. Secara lisan ada penjelasan dari Wakamad Kesiswaan dan untuk yang tertulis nya ada buku karakter yaitu dinamakan buku biru. Memberikan kesempatan kepada guru dan staf untuk berpartisipasi berupa pemberian sumbangan pikiran demi tercapainya tujuan pendidikan karakter di madrasah. Guru terlibat langsung dalam pelaksanaan pendidikan karakter karena guru pun harus mengikuti kegiatan khususnya kegiatan kokurikuler keagamaan seperti puasa senin dan kamis, shalat dhuha, shalat dzuhur dan ashar berjamaah.

Pengendalian Penetapan standar. Dilakukan dengan cara adanya standar tertulis yang dimiliki setiap kelasnya. Dilakukannya evaluasi setiap satu bulan. Kebanyakan masih belum mencapai target dan belum konsisten yang berkaitan dengan karakter contohnya seperti membersihkan ruangan kelas. Perbaikan terhadap kesalahan-kesalahan yang terjadi dilakukan evaluasi dengan cara dikurangi jika terlalu berat dan ditambahkan jika terlalu ringan satu semseter sekali diadakan evaluasi.

Hasil dari manajemen pendidikan karakter smelalui kegiatan kokurikuler keagamaan yang ditanamkan sesuai dengan perkembangan peserta didik, dan mereka memandang bahwa hal tersebut akan sangat berguna bagi kehidupannya kelak. Mengenai lulusan juga banyak yang dilanjutkan ke MA ArRaudloh karena peserta didik merasa nyaman dengan adanya kegiatan kegiatan yang dilaksanakan di madrasah contohnya dengan adanya kegiatan kokurikuler. Respon masyarakat positif dengan adanya kegiatan kokurikuler keagamaan ini. Terciptanya iklim sekolah aman, nyaman dan tertib sehingga proses pembelajaran dapat berlangsung dengan tenang. Dari segi keamanan, kenyamanan dan tertib sudah optimal.

Faktor pendukung pendidikan karakter (kekuatan): Potensi fisik dan fasilitas sarana dan prasarana, potensi tenaga pendidik, kegiatan kokurikuler keagaamaan. Faktor pendukung pendidikan karakter (Peluang): peningkatan mutu akademik dan pengembangan pendidikan karakter. Penghambat pendidikan karakter (kelemahan); Sisi manajemen Pengelolaan, sisi pengalaman pendidik, akses Jalan. Faktor Penghambat pendidikan karakter 
(tantangan): Standar mutu pengelolaan sekolah, cara pandang masyarakat terhadap pendidikan secara umum.

\section{REFERENSI}

Akhwan, M. (2008). Pengembangan Madrasah sebagai Pendidikan untuk Semua. el-Tarbawi, 1(1), 41-54. https://doi.org/10.20885/tarbawi.vol1.iss1.art4

Athoillah, A. (2010). Dasar-Dasar Manajemen. Bandung: Pustaka Setia.

Badrudin. (2013). Dasar-Dasar Manajemen. Bandung: Alfabeta.

Citra, Y. (2012). Pelaksanaan Pendidikan Karakter dalam Pembelajaran. Jurnal IImiah Pendidikan Khusus, 1(1), 237-249.

http://ejournal.unp.ac.id/index.php/jupekhu/article/viewFile/795/666

Hasanah, A. (2013). Pendidikan Karakter Berperspektif Islam. Bandung: Insan Komunika.

Isnaini, R. L. (2018). Penguatan Pendidikan Karakter Siswa Melalui Manajemen Bimbingan dan Konseling Islam. MANAGERIA: Jurnal Manajemen Pendidikan Islam, 1(1), 35-52. https://doi.org/10.14421/manageria.2016.11-03

Jahari, J., \& Syarbini, A. (2013). Manajemen Madrasah, Teori Strategi dan Implementasi. Bandung: Alfabeta.

Lestari, P. (2016). Membangun Karakter Siswa Melalui Kegiatan Intrakurikuler, Ekstrakurikuler, dan Hidden Curriculum di SD Budi Mulia Dua Pandeansari Yogyakarta. Jurnal Penelitian, 10(1), 71. https://doi.org/10.21043/jupe.v10i1.1367

Mulyasa. (2016). Manajemen Pendidikan Karakter. Jakarta: Bumi Aksara.

Rusmaini. (2017). Manajemen Pendidikan Karakter di Lembaga Pendidikan Islam. El-Idare: Jurnal Manajemen Pendidikan Islam, 3(1). Diambil dari http://jurnal.radenfatah.ac.id/index.php/El-idare/article/view/1289

Salim, A. (2015). Manajemen Pendidikan Karakter di Madrasah (Sebuah Konsep dan Penerapannya). Jurnal Keilmuan Manajemen Pendidikan, 1(2). http://dx.doi.org/10.32678/tarbawi.v1i02.1999

Setiawati, N. A. (2017). Pendidikan Karakter Sebagai Pilar Pembentukan Karakter Bangsa. Dipresentasikan pada Seminar Nasional Tahunan Fakultas IImu Sosial Universitas Negeri Medan, Medan. Diambil dari http://semnastafis.unimed.ac.id/wp-content/uploads/2017/11/27.-NandaAyu-Setiawati.pdf

Syarbini, A. (2012). Buku Pintar Pendidikan Karakter. Jakarta: As@-Prima Pustaka.

Terry, G. R. (2010). Manajemen Sumber Daya Manusia. Jakarta: Kencana.

Wibowo, A. (2013). Manajemen Pendidikan Karakter di Sekolah. Yogyakarta: Pustaka Pelajar.

Yanti, N., Adawiah, R., \& Matnuh, H. (2016). Pelaksanaan Kegiatan Ekstrakurikuler Dalam Rangka Pengembangan Nilai-Nilai Karakter Siswa Untuk Menjadi Warga Negara Yang Baik Di SMA Korpri Banjarmasin. Jurnal Pendidikan Kewarganegaraan, 6(11).

Zuhdi, A., \& Rohaniawati, D. (2012). Membangun Karakter Pendidikan Dengan Akhlak Mulia. Bandung: Alfabeta. 